\title{
The emerging approaches in the study of cognition: A review
}

\author{
Fatemeh Shafiei $^{1}$, Habibollah Ghassemzadeh ${ }^{2}$ \\ 1-Ph.D. Cognitive Linguistics, Institute for Cognitive Science Studies, Tehran, Iran (Corresponding Author). \\ E-mail: s.shafiee@alumni.ut.ac.ir \\ 2- Professor, Department of Psychiatry, Tehran University of Medical Science,Tehran, Iran.
}

Received: 07/11/2020

Accepted: 23/01/2021

\begin{abstract}
Introduction: In recent decades, different views among cognitive researchers on how cognition is formed in animals, especially humans have been emerged. Cognition and cognitive processes involve many mental processes such as attention, knowledge formation, memory, judgment and evaluation, reasoning and calculation, problem solving and decision making, perception and language production.
\end{abstract}

Aim: Investigation and comparison of emerging approaches in the study of cognition.

Method: Review of literature.

Results: New approaches to cognition such as the concepts of embodied and embedded cognition, grounded cognition, enactive cognition, and situated cognition have been compared with each other and with computational cognition as well. The findings show that the boundary between the types of new approaches in the study of cognition is so narrow that they are sometimes not even easily distinguishable from each other. Furthermore, all emerging approaches in the study of cognition are very different from the computational approach in the study of cognition.

Conclusion: The new approach to cognitive science describes cognition with a variety of attributes, most of which indicate that the new approach in the cognitive science has moved away from a purely amodal, computational approach and has opened the door to experience and the environment.

Keywords: Amodal cognition, Modal cognition, Embodied cognition, Grounded cognition

How to cite this article : Shafiei F, Ghassemzadeh H. The emerging approaches in the study of cognition: A review. Shenakht Journal of Psychology and Psychiatry. 2021; 7 (6): 126-139 .URL: http://shenakht.muk.ac.ir/article-1-1084-en.pdf

Copyright $\odot 2018$ the Author (s). Published by Kurdistan University of Medical Sciences. This is an open access article distributed under the terms of the Creative Commons Attribution-Non Commercial License 4.0 (CCBY-NC), where it is permissible to download, share, remix, transform, and buildup the work provided it is properly cited. The work cannot be used commercially without permission from the journal. 


\title{
مرورى بر رويكردهاى نوخاسته در مطالعهُ شناخت
}

\author{
فاطمه شفيعى'، حبيباله قاسمزاده׳ \\ ا.د كتراى تخصصى زبانشناسى شناختى، مو سسه آموزش عالى علوم شناختى، تهران، ايران (مولف مسئول). ايميل: S.shafiee@ alumni.ut.ac.ir

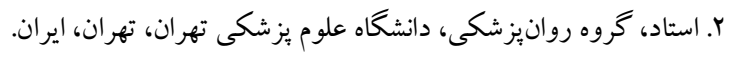

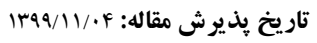

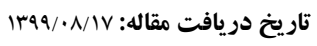

جكيده

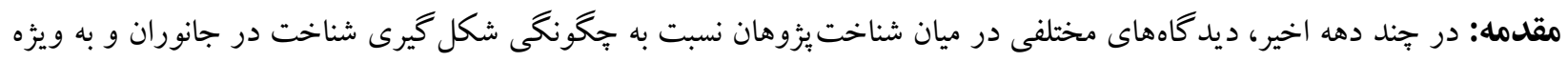

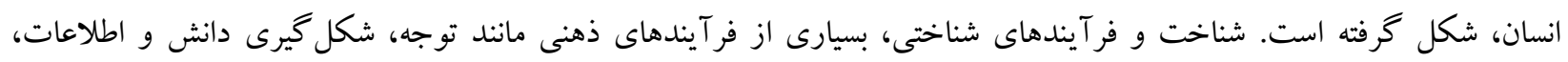

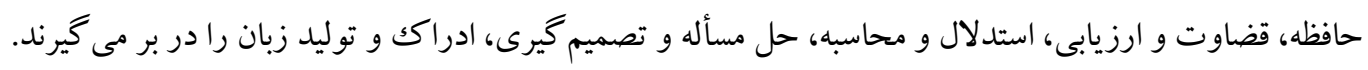
هدف: بررسى و مقايسه رويكردهاى نوخاسته در مطالعه شناخت. روش: نقد و بررسى ادبيات.

يافته ها: رويكردهاى نوخاسته به شناخت از قبيل مفاهيم شناخت جسم آكين و درونمند، شناخت يايهمند، شناخت امتدادى، شناخت

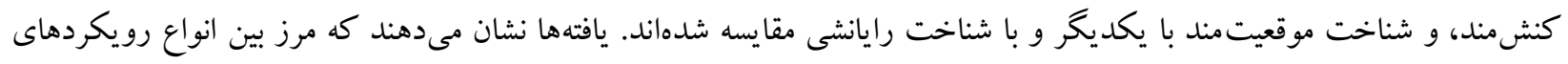
جديد به مطالعهى شناخت بسيار باريكك است، بهطورى كه گاهى حتى به راحتى از يكديخر قابل تشخيص نيستند. علاوه بر اين، تمامى رويكردهاى نوخاسته در مطالعهى شناخت، با رويكرد شناخت رايانشى تفاوت زيادى دارند.

نتيجه كيرى: رويكرد جديد به علم شناخت، شناخت را با صفتهاى گوناگونى توصيف مى كند كه اغلب آنها بيان گر آن هستند كه

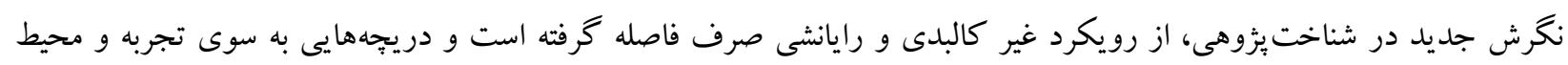
بيرامون كشوده است. كليدوازهها: شناخت غير كالبدى، شناخت كالبدى، شناخت جسم آكين، شناخت پايهمند 
فر آيندهاى شناختى از ديد گاههاى گُناگون و در زمينه-

مقدمه

هاى مختلف، از جمله، زبانشناسى، عصبشناسى و عصبيزوهى، روانشناسى، آموزش و برورش، فلسفه، انسانشناسى، و علوم رايانه مورد تجزيه و تحليل قرار مى گيرند (ون اكاردت؛؛ 1999). در اين نوشتار قصد داريم تا پِس از ذكر تاريخجِه مختصرى از مطالعات مربوط به شناخت، به رويكردهاى جديد در آن بيردازيم و در اين راستا، به مفاهيم شناخت جسم آكين ب، شناخت

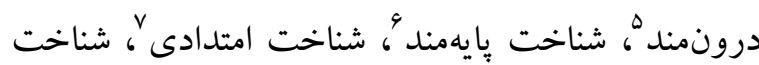
كنش مندانه، و شناخت موقعيّتمند ف اشاره خو اهيم كرد.

مطالعات مربوط به شناخت؛ از عهد عتيق تا عصر جديد

ليكاف و جانسون 'ا (1999)، شناخت را هر نوع عملكرد يا ساختار ذهنى تعريف مى كنند كه بتوان آن را بر اساس اصطلاحات و مفاهيم دقيق مورد بررسى قرار داد. بر اين اساس، مىتوان كفت شناخت به معناى عام آن، كنش فراخير زندگى و فعاليتهاى ماست. در حقيقت، شناخت، بردازش يا كنش ذهنى كسب دانش و فهميدن از طريق تفكر، تجربه و حواس است و جوهره آن را توانايى دركك كردن و واكنش نشان دادن، ذخيرهكردن اطلاعات و باز يافتن آنها، و تصميم گرفتن و دادن وِاسخهاى مناسب تشكيل مىدهد. از ديدكاه روانشناسى شناختى و در يكى از اولين تعريفهايى كه از شناخت در اولين

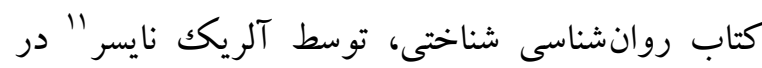

${ }^{3}$ - Von Eckardt

4- Embodied cognition

5 - Embedded cognition

${ }^{6}$ - Grounded cognition

7. Extended cognition

8 - Enactive cognition

9 - Situated cognition

${ }^{10}$ - Gorge Lakoff and Mark Johnson

${ }^{11}$ - Ulric Neisser

شناخت در انسان ' كه در اين نوشتار، از آن به شناخت ياد مىشود، به عمل ذهنى يا روند دستيابى به دانش و دركك

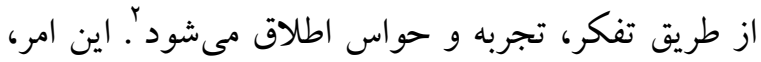
بسيارى از جنبههاى عملكردها و فر آيندهاى فكرى مانند توجه، شكل گيرى دانش، حافظه، قضاوت و ارزيابى، استدلال و محاسبه، حل مسئله و تصميم گيرى، ادراكك و توليد زبان را در بر مى گيرد كه به آنها فر آيندها يا بردازشهاى شناختى كفته مىشود. اين بردازشها در

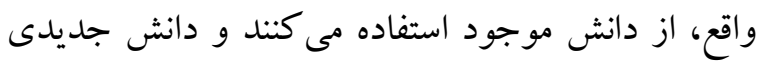
را ايجاد مىنمايند. بر اين اساس، بردازشهاى شناختى به شمارى از تكاليفى كه مغز بهطور مداوم انجام مىدهد، اشاره دارد. اين فر آيندها تمام اطلاعاتى را كه ما از محيط بيرامونمان دريافت مى كنيم، بردازش مى كنند. مغز ما اعمال گوناكونى را انجام مىدهد، از برنامهريزى براى اين كه جِكونه كام بعدى را برداريم، تا تشخيص بوى نان سوخته، تا ياد گيرى كار كردن با وسيله الكترونيكى جديد. هنگامى كه ما از بردازشهاى شناختى سخن مى گیوييم،

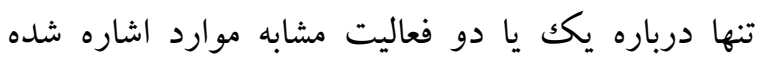

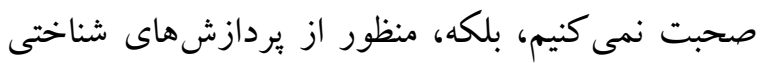
استفاده كار آمد از تمامى اطلاعاتى است كه مغز از محيط

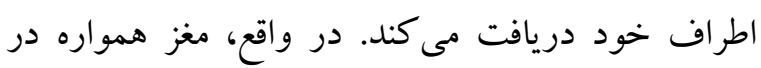
حال انجام حجم كثيرى از فعاليتهاى شناختى است:

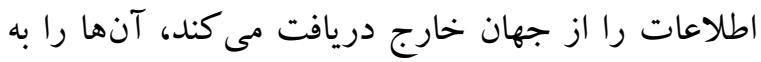
زبان قابل فهم مغزى در مى آورد و ذخيره مى كند، و در نهايت، به هنگام نياز، بازيابى مى كند و مورد استفاده قرار مىدهد. جِنين فرآيندى، اين امكان را به ما مىدهد تا با جهان اطرافمان هرجه هوشمندانهتر تعامل نماييم.

1- Hhuman cognition

2 "Cognition". Lexico. Oxford University Press and Dictionary.com. Retrieved 6 May 2020. 
ييش از اين، شناخت، با افلاطون و بهويزه، ارسطو و علاقه

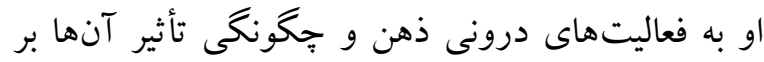
تجربه بشرى آغاز كشته است. رويكرد افلاطون به مطالعه ذهن بر اين اساس بود كه افراد، جهان را ابتدا از طريق تشخيص اصول بنيادينى كه در درون آنها ذاتى است، درك مى كنند و سبس، تفكر انديشمند را براى آفرينش

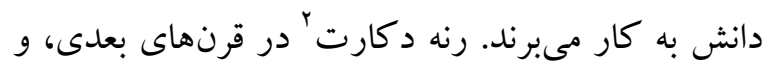

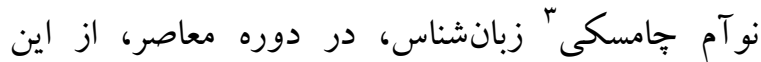
نخرش دفاع كردند؛ اما ارسطو بر اين باور بود كه آدميان، از طريق مشاهده، دانستن و شناختن، جهان بيرامون خويش را تجربه مى كنند (ادى"'، 19.ب). ارسطو به جنبههاى شناختى مربوط به حافظه، ادراك، و تصويرسازى ذهنى متمر كز بود و در اين راستا، به جمع آورى اطلاعات از طريق مشاهده و آزمايش تأكيد بسيارى مىورزيد

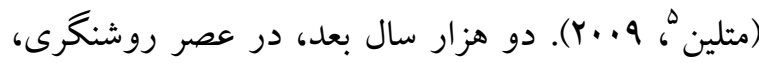

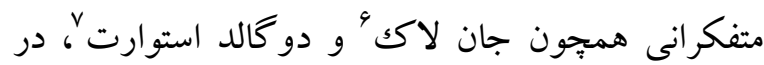
جستوجوى مدلى از ذهن بودند كه در آن، ايدهها

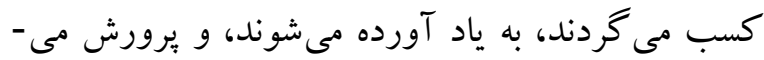
يابند. اين فيلسوفان زمينه را براى طرح مفاهيم نوين

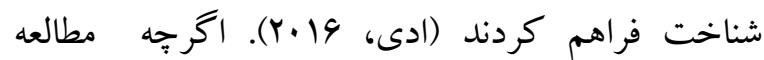
شناخت، سابقهُ ديرينه در تاريخ روانشناسى دارد.--رر نيمه دوم قرن بيستم بود كه با بيشرفت تكنولوزى، بثزوهش هاى كستردهاى درباره شناخت انجام گرفت. مطالعه شناخت، امروزه بر شاخههاى مختلف روانشناسى سايه افكنده و باعث ارتباط بيشتر آن با ساير رشتهاى علمى مانند عصبشناسى، زبانشناسى، و رايانه شده است. روان-

${ }^{2}$ - Rene Descartes

${ }^{3}$ - Noam Chomsky

${ }^{4}$ - Eddy

5 - Matlin

${ }^{6}$ - John Locke

${ }^{7}$ - Dugald Stewart
سال 199V ارائه شد، شناخت، اين گونه تعريف مىشود: شناخت به آن دسته از فر آيندهايى كفته مىشود كه به وسيله آنها، دادههاى حسى دستخوش دگر گونى و انتقال مى گردند، تلخيص يافته يا بسط داده مىشوند، ذخيره شده و مورد بازيابى و سرانجام مورد استفاده قرار مى - ركى

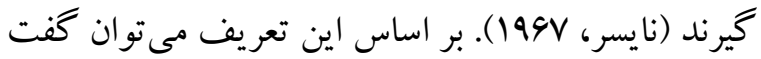
شناخت، در بر كيرنده همه بردازشهاى آكاهانه و

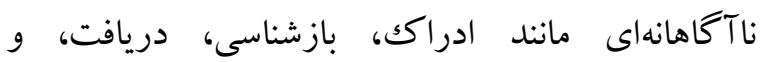
خردورزى است كه از طريق آنها، دانش يا معرفت انباشته مىشود. به سخن ديخر، به كليه انديشهها، دانشها، تفسيرها، دريافتها، و افكار هر فرد شناخت كفته مى -

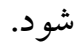
تولد مفهوم شناخت را معمولاً به همايشى كه درباره نظريه اطلاعات در سال 1909 و در " انستيتو تكنولوزى ماساجوست (MIT)" تشكيل شده است، مربوط مىدانند؛ اما سعى براى درك ذهن و عملكرد آن، حداقل به زمان يونانيان و فيلسوفانى از قبيل افلاطون و ارسطو مىرسد. از

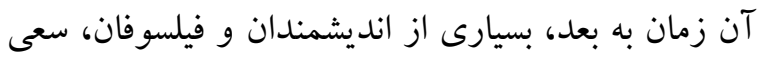
كردند به نحوى ماهيت دانش و شناخت را در انسان، مورد بحث و نظر قرار دهند (قاسمزاده، هیץ|). در ادامه، به تاريخجه مختصرى از مطالعات شناخت و معرفى برخى از بيشگامان آن مى بردازيم و سبس به رويكردهاى معاصر

$$
\text { به شناخت اشاره خواهيم كرد. }
$$
كاربرد شناخت به معنى تفكر و آكاهى، از نظر تاريخى،

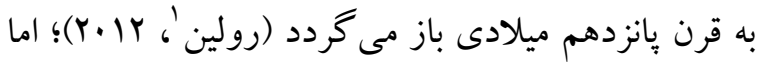

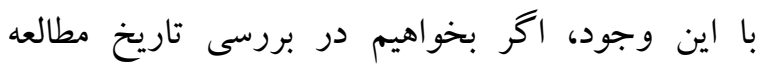

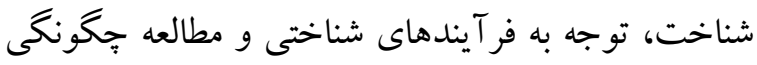
فكر كردن رادر نظر بخيريم، مىتوانيم بخوييم كه قرنها

${ }^{1}$ - Revlin 
جهت يابى، از نوعى نقشه ذهنى استفاده مى كنند (فريدنبرك و سيلورمن، 19. (Y). تقريباً همزمان با اين نوع تبيينهاى رفتارى_شناختى، تحقيقات دامنهدارى در ارويا و روسيه در جريان بود.

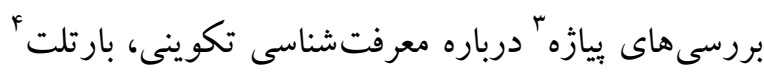

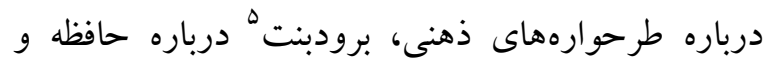

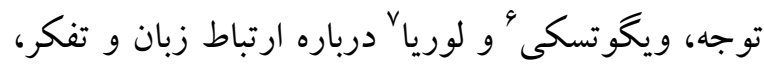
نمونهاى از اين تحقيقات به شمار مىروند (فريدنبرگك و سيلورمن، (Y) (Y). ييازه، سالهاى زيادى از عمر خود را صرف ارائه تعريفى از تحول شناختى كرد. او بر تفكر منطقى تأكيد داشت و بر اين اساس، نظريه او به تفكر علمى و تحول آن بسيار نزديك است. ويخو تسكى نيز به

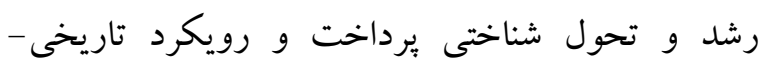
اجتماعى را در تحول شناختى بيان نمود. او در مطالعه رشد و تحول شناختى، بر روشى تأكيد مى كرد كه در آن، رشد و تحول شناختى، از طريق تعامل اجتماعى، تجارب فرهنگى، و درونى سازى ابزارهاى شناختى حاصل مى گردد. همجنين، ويگوتسكى در جريان رشد و تحول كودكان بر نقش تعامل اجتماعى از طريق زبان، تأكيد

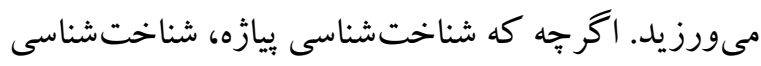
تحولى يا تكوينى است و هدف او، مطالعه نحوه ايجاد و تكامل فعاليتهاى شناختى انسان، از اوايل كودكى تا

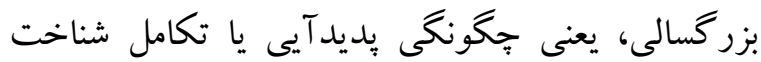

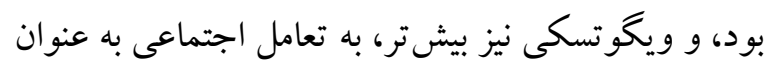
منبع اوليه و بنيادين شناخت و رفتار مىنخريست، بايد توجه كرد كه هم ويخوتسكى و هم بيازه، در تاريخ

3. Piaget

4- Bartlett

5 - Broadbent

6 - Vygotsky

${ }^{7}$ - Luria
شناسى در آغاز بر مطالعه كنشهاى ذهن متمركز بود. منظور از كنشهاى ذهن: تمامى فعاليتهايى است كه دستاورد فعاليتهاى مغز تلقى مىشود. از زمان تأسيس آزمايشگاه روانشناسى، در سال 1AV9، بر مطالعه ذهن تأكيد مى شد؛ موضوعى كه بعدها به شناخت تغيير نام داد

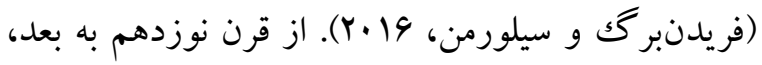
ذهن و فعاليت ذهنى، به طور جدى ترى موضوع مطالعه روانشناسى قرار گرفت؛ اما با اين وجود، تا اوايل قرن بيستم، همجنان، روانشناسى تا حد زيادى تحت تسلط رويكردهاى ساختارگرايى مبتنى بر دروننگرى و گاه روان تحليلى قرار داشت كه هيج يكك از اين رويكردها به طور مستقل به مطالعه شناخت نمىيرداختند. با اين حال، برخى از اين رويكردها، مانند رفتارگرايى كه اتفاق هيجانانگيزى براى روانشناسى محسوب مى شد، كرجه خود، مطالعه ذهن رادر دستور كار قرار نداد؛ اما مقدمه اى براى بررسىهاى دقيق درباره ذهن در قرن بيستم شد.

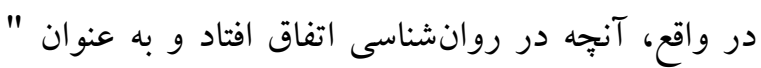
انقلاب شناختى" نام گرفت، در درجه نخست، حاصل فعاليت رفتارگرايانى بود كه براى تبين برخى رفتارهاى حيوانات در تحقيقات يادگيرى، از سازههاى نظرىاى استفاده مى كردند كه جندان ساز گارى با رفتارگرايى راديكال نداشت (فريدنبر گك و سيلورمن، 19 +r). براى مثال، مىتوان به ادوارد تولمن ' كه در سنت رفتارگرايى كار مى كرد، اشاره نمود. او به دنبال مسائل شناختى مانند

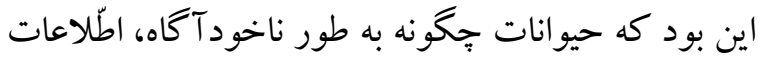
فضايى (مكانى) را به صورت نقشه هاى شناختى از محيط بيرامونشان باز مىنماياند (ويلسون و كيل'، 1999) و در اين راستا، به اين نتيجه رسيد كه موشها در آزمايشهاى بـ

\footnotetext{
1- Tolman

- Wilson \& Keil
} 
رفتار، را مانند تعريف فيزيكك به خواندن اعداد كنتور توصيف كرد. از نظر او، اگر قرار بود روانشناسى علمى موفق شود، مىبايست مفاهيم ذهنى با دادههاى رفتارى تركيب شوند و تبينى در اين باره فراهم آورند (ميلر، r...... در اين زمان بود كه رفته رفته، روند مطالعات روانشناختى به سمت و سويى رفت كه در دهه هاى بعدى

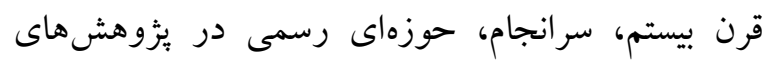
مربوط به شناخت شكل گرفت كه به روانشناسى شناختى مشهور شد و به همر اه زبانشناسى، عصبشناسى، فلسفه، انسانشناسى، و علوم رايانه در دهه .199 بايههاى شكل گيرى انقلاب شناختى را بنيان نهادند و از آن زمان تا كنون، بزوهشخران متعدد از حوزههاى مطالعاتى كوناكون به بررسى ابعاد مختلف شناخت و شناخت-

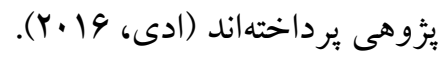

\section{رويكردهاى جديد در مطالعه شناخت}

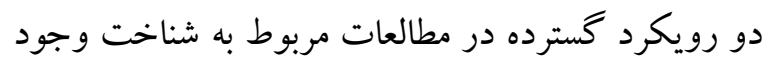
دارد: يكى رويكرد بردازش اطلاعات است كه تلاش مى كند فر آيندهاى خردورزى و تفكر انسان را از طريق مقايسه ذهن (يا مغز) با سيستمهاى رايانشى بيجيدهاى بفهمد كه براى اكتساب، بردازش، ذخيره، و كاربرد

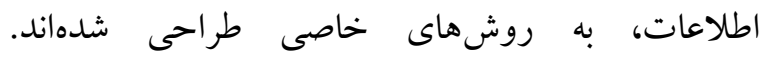
يُزوهشگران اين حوزه، تلاش مى كنند با ايجاد برنامههاى

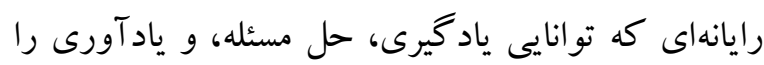
دارند، نظريه يكيارجه شناخت را رشد و گسترش دهند. در اين رويكرد كه به نظريههاى كلاسيك مطالعات شناخت شناخته مىشود، بازنمايىهاى اساسى و محورى در شناخت را دادهها و اطلاعات غير وجهى يا غير
مطالعات مربوط به شناخت از نقش اثر گذارى برخوردار

$$
\text { هستند (شولتز و شولتز '، V... }
$$

ميانه دهه •190 بود كه معلوم شد رفتار گرايى نمىتواند

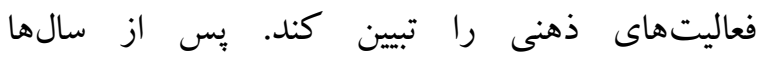
ناديده گرفتن مفاهيم مربوط به ذهن توسط رفتارگرايان،

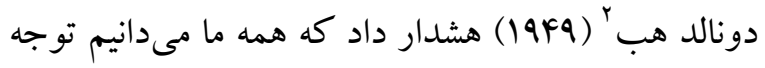
(به معناى تخصصى آن)، وجود دارد؛ بنابراين، بهتر است اسكلتش را در آوريم و راز آن را بر ملا سازيم! در اين ميان، دونالد برودبنت (1994-1949)، با كارهاى تجربى خودش و نيز، تجزيه و تحليل يافته هاى ديخران، بيش از هر فرد ديخرى بر اين اسكلت، نور تابانيد و نشان داد كه لهري روانشناسى تجربى، مىتواند ماهيت فر آيندهاى شناختى را آشكار سازد. با بررسىها و مطالعات او، رويكرد يردازش اطلاعات به دركك توجه، ادراكs و حافظه، به

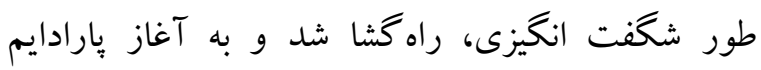
معروف به انقلاب شناختى، دامن زد (ويلسون و كيل، 1999). البته، بايد توجه كرد كه بيزوهشهاى اوليه برودبنت، كاملاً تحت تأثير كارهاى بارتلت بود. بارتلت (19Rr)، بر اين نكته تأكيد داشت كه افراد، يردازش گرهاى ساختارساز فعال هستند. او تحريفهاى نظاممندى را كه افراد در حين يادآورى رويدادهاى داستانهايى كه برايشان نآشنا بود و به آنها گوش داده بودند، مورد تجزيه و تحليل قرار داد و مفهوم طرحواره يا ساختواره ذهنى بّ را به عنوان سازههاى بازنمايىهاى

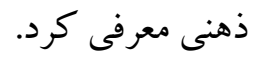
جامسكى، انديشمند ديخرى كه در شكل گيرى انقلاب شناختى، نقش مؤثرى داشت، نيز نسبت به رفتارگرايى واكنش نشان داد و تعريف روانشناسى به عنوان علم

\footnotetext{
1- Schultz \& Schultz

2 - Donald Hebb

3 - Schema
} 
اثر گذار است. اين سه حالت عبارتاند از: حالت فعال كه شامل بازنمايى به واسطه كنش است، حالت نمايهاى كه از تصويرهاى ذهنى و ديدارى بهره مىبرد، و حالت نمادين كه كاربرد زبان است (دويگنان، IV) رويكرد كلى، در سالهاى اخير، روند جديدى در شناخت يُزوهى براى توضيح شناخت يديد آمده است؛

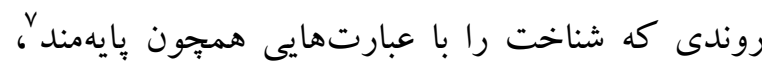

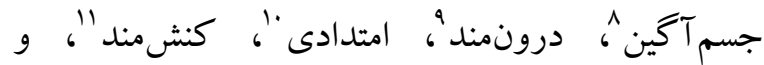

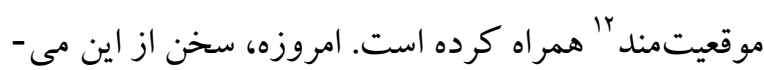
رود كه شناخت، امرى جسمانى شده و آميخته با احساس و ادراكك است. حتى در بالاترين سطح نيز، شناخت،

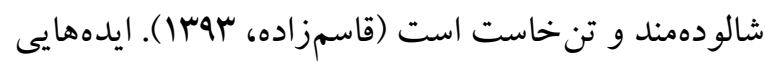
كه در اين زمينه بيان شدهاند، بسيار متنوع هستند و يرداختن به تمامى جنبههاى آنها فراتر از بحث فعلى است؛ اما تلاش مىشود به سه مفهوم سازه نظرى كه در تعريف شناخت، تقريباً، اصلى و بنيادى هستند، يعنى،

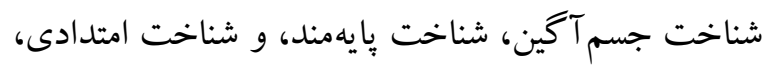
مفصلتر اشاره كرد و سه مفهوم سازه نظرى ديخر، يعنى شناخت درونمند، كنشمند، و موقعيتمند را در حد

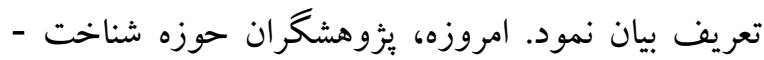
بثزوهى بر اين باورند كه شناخت، تنها به مغز وابسته نيست و جسم نيز در شكل گيرى آن نقش دارد. اين ديد ديد گاه شناخت جسم آكين مشهور است. از سوى ديخر، كروهى نيز قائل به آناند كه فعاليت شناختى به طور معمول، از ساختارهاى محيط اجتماعى و طبيعى، بهرهمند

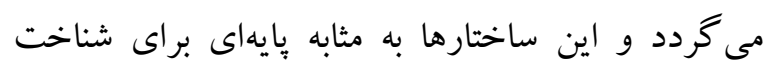

كالبدى' تشكيل مىدهند كه تقريباً مستقل از سيستمهاى كالبدى' مغز در فرآيندهاى ادراكى، تفكر و عمل سل يردازش مىشوند. از اين ديدگاه، بازنمايىهاى شناختى، با بازنمايىهاى مربوط به سيستم كالبدى فرق دارند و در

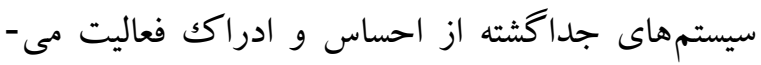
كنند (قاسمزاده، سوسا). نكته قابل توجه در نظريههاى سيستمهاى غير كالبدى آن است كه موقعيتها و مؤلفه هاى شناخت را در بردازش مفهومى بعدى، نمادهاى غير كالبدى بازنمايى مى كنند؛ بنابراين، نمادهاى كالبدى كه در اصل، اين انتقالها را توليد نمودهاند، فعال نمىشوند.

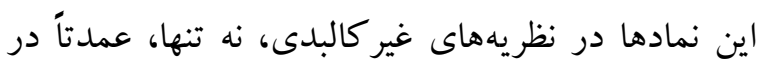

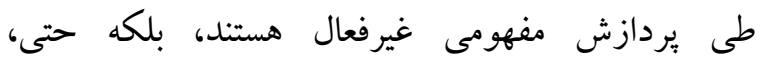
وجودشان براى جنين كارى اصلاً ضرورى نيست و در عوض، همه معناى يكك صحنه تجربهشده را نمادهاى غير كالبدى به دوش مى كشند (شفيعى و قاسمزاده،

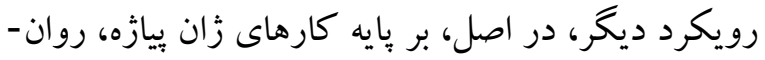
شناس سويسى كه بحث انطباق شناختى را در قالب دو

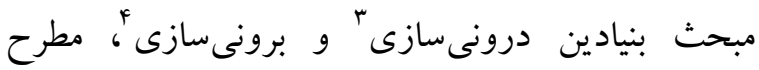
كرده، شكل گرفته است. درونىسازى، فرآيند تفسير واقعيت بر حسب الكوى درونى فرد از جهان و بر اساس تجربه ييشين او است. از طرف ديخر، برونىسازى، بيانگر تغييراتى است كه فرد از طريق فر آيند انطباق با تجربه، در آن مدل قبلى ايجاد مى كند (دويخنانه، جروم برونر، ، روانشناس آمريكايى، مفهوم مطرح شده توسط بيازه را كسترش داد و بيشنهاد كرد كه سه حالت بر فر آيندهاى شناختى كه جهان را بازنمايى مى كنند،

\footnotetext{
- Amodal

2- Modal

3 - Assimilation

${ }^{4}$ - Accommodation

5 - Duignan

${ }^{6}$ - Jerome Bruner
} 
شناخت جسم آكين را در دهههاى اخير، دوباره مطرح كردند و با اين ايده، بسيارى از ديدگاههاى فلسفى كذشته

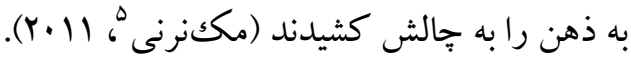
نكرش كلاسيك علم شناخت به شناخت، در واقع، همان

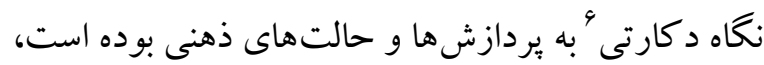
اين نخرش، بر اين باور است بردازشها و حالتهاى برداى ذهنى، منحصراً درون كاسه سر هر فرد يا موجود زين زنده جاى كرفتهاند. علم شناختى دكارتى، اين نخرش را از طريق مطرح نمودن بازنمايىها و اعمال ذهنى كه بر آن بازنمايىها صورت مى يذيرند، گسترش داد. از نكاه اين رويكرد، فرآيندهاى شناختى از دست كارى و تغيير و تحول ساختارهايى به وجود مى آيند كه اطلاعات مرتبط با جهان را در خود حمل مى كنند. اين ساختارهاى حمل كننده اطلاعات، بازنمايىهاى ذهنى نام دارند و بر اساس

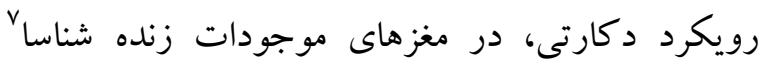
جاى گرفتهاند. در واقع و به بيان ديخر، در اين نوع

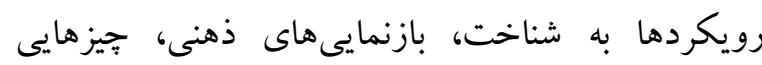
هستند كه تنها در مغز يافت مىشوند و تغيير و تحول در آنها نيز از طريق بردازشهايى رخ مىدهد كه در مغز انجام مىشود. فرآيندهاى شناختى نيز جيزى جز همين

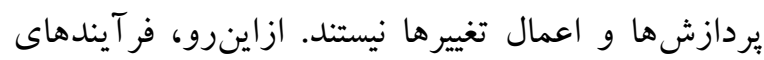
شناختى همان يردازش هاى مغزى هستند و منحصراً توسط اين بردازشها محقق مىشوند و دست كارى و تغيير بر آنها نيز اتفاقى نيست و بر اساس اصول و قوانينى انجام مى گيرد. به همين دليل، از اين رويكرد كاهى با نام رويكرد بازنمايىها و قوانين در دركك شناخت ياد مىشود كه در آن، هم قوانين و هم بازنمايىها نورونى هستند و

5 - McNerney

${ }^{6}$ - Cartesian

7- Cognizing
عمل مى كنند. اين گروه شناخت را يايهمند در نظر مى كيرند و سرانجام، انديشمندانى نيز مرزهاى شناخت را به فراتر از موجود زنده كسترش مىدهند و شناخت را امتدادى در نظر مى گيرند. در نتيجه از اين ديدگاه نمى توان از بازنمايىهاى شناختى غير كالبدى و مستقل از سيستمهاى كالبدى مغز و جسم سخن كفت. در واقع، اين ديد گاه كمكك مى كند تا تصويرى از فعاليت ذهنى، بسته به موقعيت يا بافتى كه تجربه در آن رخ مىدهد، خواه اين

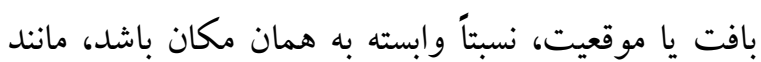
آنجه شناخت جسم آكين مطرح مى كند، و خواه تا حدى فراكير باشد مانند جيزى كه شناخت بايهمند و امتدادى به

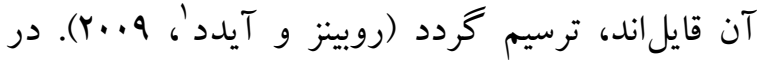
ادامه، مفاهيم مطرح شده در اين ديدگاه را به طور خلاصه، از نظر مى كذرانيم.

\section{شناخت جسم آكين}

تجزيه و تحليل جنبههاى جسم آكين ادراك و شناخت را مىتوان در آثار اوليه هوسرل بيدا كرد. هوسرل (IN9V) به نقش جنبش (حس و حركت) در ادراك اشاره كرده است و اعتقاد دارد كه جنبه هاى جسم آكين تجربه، در

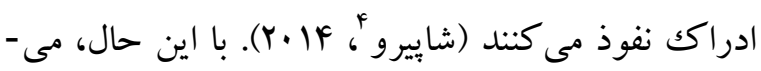
توان كفت كه ايده شناخت جسم آكين تاريخجه نسبتاً كو تاهى دارد و ريشههاى فكرى آن، بيشتر به اوايل قرن بيستم و فيلسوفانى مانند هايدگر، مرلويونتى، و جان ديويى باز مى گردد و فقط تنها در جند دهه كذشته، به صورت تجربى مورد مطالعه قرار گرفته است. جورج ليكاف و مارك جانسون، دو انديشمندى بودند كه ايده

\footnotetext{
- Robbins \& Aydede

2- Husserl

3- Kinaesthetic

${ }^{4}$ - Shapiro
} 
شدت به ويز گى هاى جسم فيزيكى كنش گر وابسته است؛ به اين معنى كه جنبه هايى از جسم كنش گرى، فراتر از مغز، نقش سازنده عليتى يا فيزيكى در بردازش شناختى ايفا مى كند. بر اساس ديد كاه شناخت جسم آكين، انديشهها، بدون درگيرشدن جسم در حس و عمل، خالى خواهند شد و امور ذهنى، ويز گیىها و خصوصيتهايى را كه اكنون دارند، ديخر به نمايش نخواهند كذاشت. به طور كلى، ديد گاههاى غالب در فلسفه ذهن و علم شناخت، براى جسم، در دركك ماهيت ذهن و شناخت، نقشى حاشيهاى قايل هستند. اين در حالى است كه طرفداران شناخت جسم آكين، اين ايده را امر اشتباهى مىدانند. در

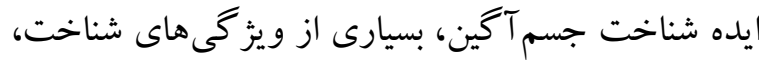
خواه در انسان باشد، خواه در ساير موجودات، از طريق جنبههايى از كل جسم موجود زنده شكل مى گيرد. بر اين اساس، جنبههاى مختلف جسم كه دربر گيرنده سيستم حسى و حر كتى، نظام ادراكى، و تعاملات بدنى با محيط است، در شكل گيرى شناخت در انسان كه شامل ساختارهايى ذهنى عالىتر مانند خردورزى، قضاوت، درك مفاهيم و مقوله ها، و غيره است، نقشى بنيادين دارد. از اين رو، بر اساس نظريه شناخت جسم آكين، اين تنها ذهن و مغز نيست كه بر جسم مسلط و تأثير گذار است، بلكه جسم نيز به نوبه خود بر ذهن و كسب شناخت اثر مى كذارد. اين سخن به معناى آن است كه شناخت ما لـ له محدود به قشرهاى مخمان نمىشود و تحت تأثير، و يا شايد حتى تعيين، تجربههاى جسم ما است (ويلسون و

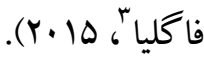

\section{شناخت يֶايهمند}

3- Wilson \& Foglia
درون مغز موجود زنده شناسا شكل مى گيرند (لمن'، .$(199 \mathrm{~V}$ رويكرد جديدتر در مطالعه شناخت، رويكردى است كه علم شناختى غير دكارتى 'نام دارد. اين رويكرد، با رد فرض رويكرد دكارتى مبنى بر رخ دادن تمام يردازش هاى شناختى در درون مغز، بر اين فرض استوار است كه حداقل، برخى از يردازشهاى ذهنى، ولى نه همه آنها، تنها به وسيله بردازشهاى رايانشى مغزى صورت نمى يذّيرند، بلكه تركيبى از بردازش هاى مغزى و ساختارهاى بدنى گستردهتر در شكل گيرى آنها دخالت دارند. اين تفكر، به ايده ذهن جسم آكين معروف است و بر اساس آن، ذهنها عميقاً جسمهايى را كه در آنها جاى دارند،

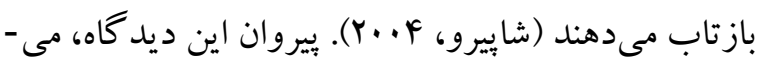
كويند كه بردازشهاى روانشناختى بدون دخالت جسم، ناتمام مىمانند و فر آيندهاى ادراكى، شامل ساختارهاى جسمى نيز هستند و به آنها بستكى دارند. براى مثال، يك موجود زنده با دارا بودن جسمى غير انسانى، داراى مختصات روانشناختى بينايى و شنوايى غير انسانى خواهد

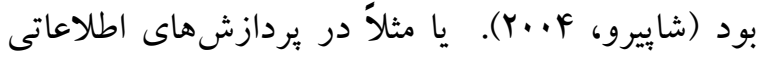
ديدارى كه مربوط به عمق مغز هستند، مغز، اطلاعات را بر اساس فاصله ميان دو جشم قرار مىدهد. اخر تعداد جشمها بيشتر يا كمتر از از دو باشد، يا اين كه فاصله جشمها تغيير كند، يردازشهاى مربوط به عمق مغز نيز تغيير مى كند. اين به معناى آن است كه: "بينايى انسانى،

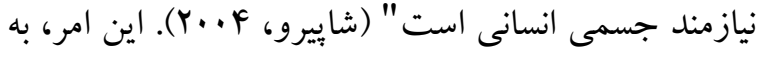
طور مشابه، درباره ديخر توانيىهاى ادراكى نيز صادق است؛ اما بر اساس آنجه ذكر گشت، هنگًامى كه كفته مىشود شناخت جسم آكين است، منظور آن است كه به

\footnotetext{
1- Lemmen

${ }^{2}$ - Non-Cartesian
} 
اين رويكرد اين است كه حداقل برخى از فرآيندهاى ذهنى، و نه همه آنها، به محيطى كه موجود زنده رادر بر گرفته است، گسترش مىيابد و تفسير بخشى از كنش هاى آن، توسط جهان اطرافش صورت مى گيرد. منظور از فر آيندهاى ذهنى، مسلماً، همان فر آيندهاى شناختى است و كنشهايى كه آن موجود شناختى بر جهان بيرامون خود انجام مىدهد نيز، دستكارى، بهرهبردارى و تغيير ساختارهاى بيرونى است. آنجه اين ساختارها را از هم متمايز مى كند، اين است كه آنها اطلاعات مربوط به انجام يكك فعاليت شناختى مشخصى را در اختيار دارند و موجود زنده با انجام عمليات بر اين ساختارها به روشهاى مناسب، قادر است آن اطلاعات رادر اختيار خود و عمليات شناختى بعدىاش قرار دهد. يعنى عملى كه توسط اركانيسم شناختى بر اين ساختارها انجام مىشود،

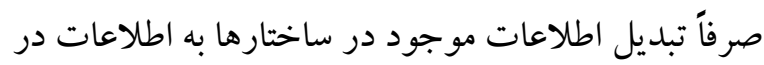
دسترس اركانيسم و يا عمليات بردازشى بعدى آن است.

\section{شناخت درونمند}

نظريه شناخت درونمند بر اين باور است كه تعامل جسمى بدن و جهان به شدت، رفتارهاى احتمالى موجود

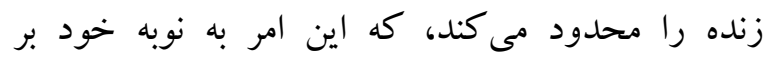
فر آيندهاى شناختى كه از تعامل بين موجود زنده و جهان اثر مىيذيرد و در واقع، تا حدودى بر اساس آن شكل مى گيرد، تأثير مى كذارد. نظريه شناخت درونمند نيز ماند نظريه شناخت جسم آكين، واكنشى صريح به نظريه شناخت رايانشى است كه اعتقاد دارد نظامهاى بردازشى، اساساً نظامهاى بازنمايى رايانشى هستند كه اطلاعات ورودى را دريافت مى كنند و با بردازشهاى دورنى، برونداد توليد مى كنند. به طور كلى، دو نظريه شناخت جسم آكين و درونمند، اغلب در كنار هم و به صورت
شناخت جسم آكين كه ييش از اين، به آن اشاره شد، در بسيارى از موارد با شناخت بايهمند همراه شده است. منظور از شناخت بايهمند، شناختى است كه محيط بر آن اثر مى گذارد. در واقع، مفهوم شناخت يايهمند نيز مانند شناخت جسم آكين بيانگر اين نكته است كه اشتباه است اگر فكر كنيم بدن و محيط، تنها افزونهايى به عملكرد ذهنى يا فر آيندهاى مغزى خودگ خردان هستند. بلكه در مقابل، بر اساس شناخت يايهمند، فر آيندهاى ذهنى به طور تمام و كمال بر اساس بردازشهاى مغزى درونى يا حتى يردازشهاى جسمى حاصل نمىشوند و اين فرآيندها شامل وبردازشهاى محيطى هم هستند. در اين نكرش، زيرمجموعهاى از فرآيندهاى ذهنى با بردازش هاى محيطى ساخته مىشوند. در نتيجه، وقتى كفته مىشود بردازشهاى ذهنى پايهمند هستند، منظور آن است كه كاركردشان در محيط بيرونى مرتبط اتفاق مىافتد

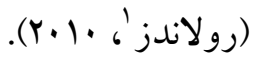

\section{شناخت امتدادى}

در راستاى ديدگاه غير دكارتى، ديدگاه سومى هم به شناخت وجود دارد كه با نام شناخت امتدادى شناخته مىشود. به اين نوع شناخت، نامهاى متعدد ديخرى هم جون برونگ

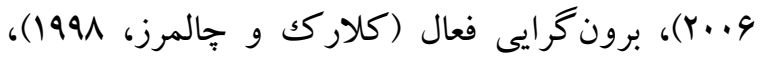
محيط گرايى (رولاندز، 1999)، و برون گرايى جايگاهى

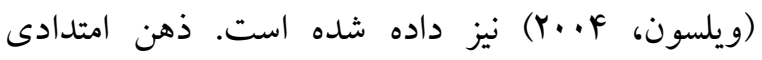

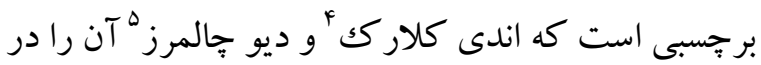
مقاله سال 1991 خودشان، مطرح كردند. ايده كلى در

\footnotetext{
- Rowlands

2- Vehicle externalism

3 - Harley

4 - Andy Clarck

5 - Dave Chalmers
} 
اين رو، در نظر يك كنش گرأ؛ سيستمى شناختى به حساب مى آيد كه بتواند با رفتارش موجوديت خودش را حفظ كند (آندرينگاه و همكاران، ها •Y).

\section{شناخت موقعيت مند}

شناخت موقعيت مند نظريهاى است كه مى گويد شناخت و و كسب دانش از عمل جدا نيست. اين نظريه بر اين باور است كه همه دانش و معرفت، به فعاليت هايى كه در بافت

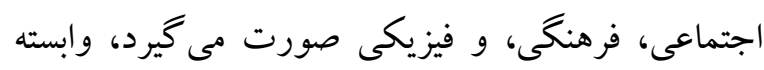

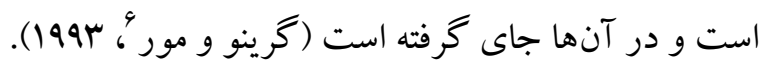
شناخت موقعيت مند طيف وسيعى از مواضع نظرى را در بر مى گيرد كه همگیى آنها در اين فرض با يككديخر مشتركاند كه شناخت به طور ذاتى با بافت اجتماعى و فرهنگى كه در آن اتفاق مىافتد، بيوند خورده است. تمام رويكردهاى شناخت موقعيتمند، وامدار نظريههاى دو روانشناس روسى، يعنى ويخو تسكى و لئونتيف \هستند.

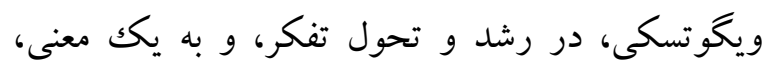
شناخت، بر نقش تعامل اجتماعى و سيستم نشانهاى متمر كز بود. او بر اين باور بود كه ذهن تعامل اجتماعى را

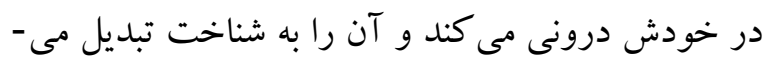
نمايد و از اين راه، خودش را مىسازد. لئونتيف از

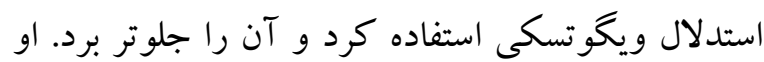
كفت كه تعاملهاى جهره به جهره كه در شيوههاى فرهنگى در بر گيرنده آنها جاى گرفتهاند، دامنه رشد ذهنى و فكرى را كستردهتر مىسازند (كُب، ا. (Y). جوهره نظريههاى شناخت موقعيتمند اين است كه كسب شناخت از بافت بيرامون جدايىنايذير است. دانش

4- Enactivist

5 - Andringa

6. Greeno \& Moore

7 - Leont'ev

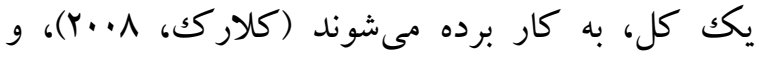
نظريههايى هستند كه دركك بهتر شناخت را از طريق تعامل يوياى منابع عصبى، جسمى و محيطى دنبال مى كنند. با اين حال، تفاوتهاى ظريفى نيز با يكديخر دارند. همان گونه كه در بخشهاى ييشين اشاره شد، شناخت جسم آكين به ويز كى هاى جسمى بدن وابسته است و اين سيستم حسى و حر كتى است كه ذهن را مىسازد (روبينز

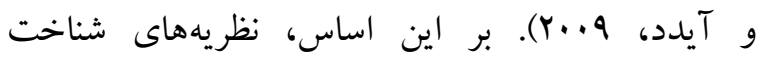
جسم آكين، به دنبال بررسى اين نكته هستند كه جسم افراد جه گُنه به آنها در شكل گيرى تفكر يارى مى رساند؛ اما شناخت درونمند، بيشتر بر نقش محيط در شكل گيرى شناخت تأكيد دارد و اين نكته را بررسى مى - رست كند كه جه گونه ويز گیىهاى محيط بير امون افر اد به آنها كمك مى كند تا توانايى هاى شناختى خودشان را بهبود

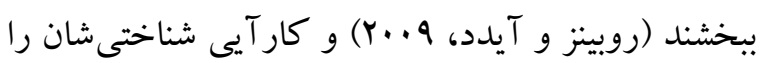

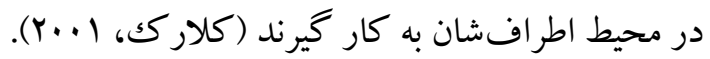

\section{شناخت كنش مند} رويكرد كنشمندانه به شناخت مبتنى بر اين فرض است كه شناخت به طور اساسى به بدن موجود زندهاى وابسته است كه به عنوان يكك سيستم خودمختار در محيطى باز و بييجيده شناخته مىشود. رويكرد كنشمندانه، مبتنى بر مفاهيمى مانند خودگردانى، جسم آگينى، حس كردن

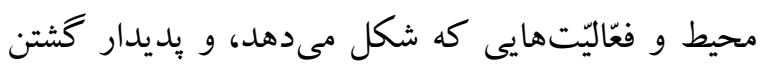
كاركردها و رفتارهاى ناشى از تعامل بين فرد و محيط

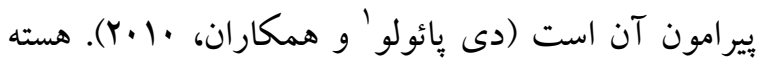

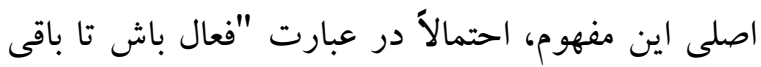

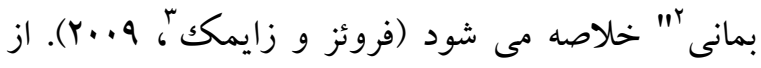

\footnotetext{
1- Di Paolo

2- Being by doing

${ }^{3}$ - Froese and Ziemke
} 
و زبانشناسى اجتماعى بهره برده است (براون و همكاران،

.$(1919$

\section{نتيجه كيرى}

همانطور كه در بخش هاى بيشين و در تعريف و توصيف

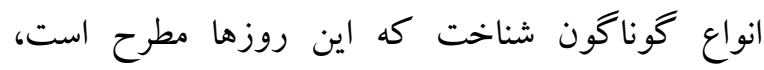
مشاهده مىشود، مرز بين اين انواع، بسيار باريكك است، بهطورى كه كاهى حتى به راحتى قابل تشخيص نيست. در شكل ا مؤلفه هاى اصلى شكل گيرى شناخت از ديدگاهـ هاى مختلف به تصوير كشيده شده است.
و معرفت، در موقعيت وجود دارد كه آن هم از افراد ديگر، فرهنگك، زبان، و جامعه جدا نيست. از اين رو، يادگيرى در اين رويكرد، از انباشتن دانش حاصل نمى كردد و فرد بايد به طور دايم در جهت كنشهاى موثر كام بردارد. بر اين اساس، مىتوان كفت كه اين ديد كاه،

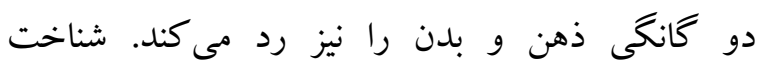
موقعيتمند در اواخر قرن بيستم، در حوزه روانشناسى تعليم و تربيت قرار گرفت؛ اما با اين وجود، از بسيارى از مفاهيم و اصول مكتب فرانكفورت و اصول تفكر انتقادى فريره، و نيز انسانشناسى، فلسفه، تحليل كفتمان انتقادى،

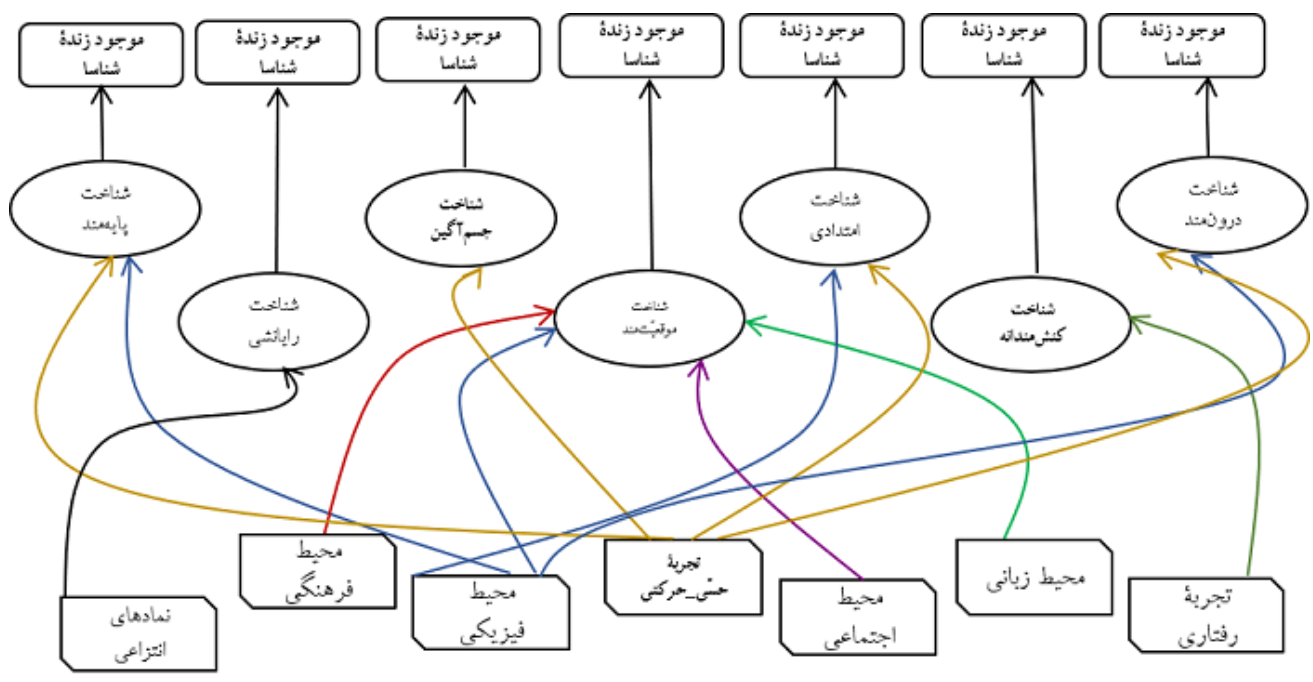

شكل 1 مؤلّفهاى اصلى شكل تيرى شناخت در ديد كاههاى مختلف

نماييم، اين شباهتها و وجوه اشتراككها هستند كه راهكشا هستند؛ بنابراين، مىتوان نتيجه گرفت كه رويكرد

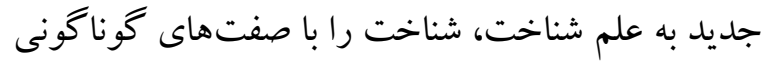
توصيف مى كند كه اغلب آنها بيانكر آن هستند كه نكرش جديد در شناختئزوهى، از رويكرد غير كالبدى و رايانشى صرف فاصله گرفته است و دريجههايى به سوى تجربه و محيط بير امون گشوده است. نكته ديكرى كه به نظر مىرسد در اين نوشتار قابل توجه باشد، اين
بر اساس اين طرحواره، به نظر مىرسد تنها ميان شناخت رايانشى و ساير انواع شناخت شكافى عميق وجود دارد، و به هيج عنوان نمىتوان بين اين نوع شناخت و كونهاى

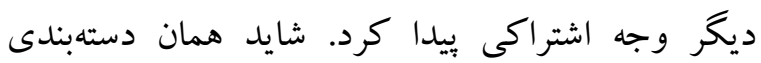
اصلى شناخت دكارتى و غير دكارتى، در مرحله اول، دستهبندى دقيقترى باشد. سبس، ميان انواع شناخت در ديد كاه غير د كارتى، بيش از آن كه بخو اهيم دستهبندى هايى بر اساس تفاوتها ارايه كنيم و آنها را تعريف 
Duignan B. (2017). Cognition, thought process. Encyclopedia Britannica.

Eddy MD. (2016). The Cognitive Unity of Calvinist Pedagogy in Enlightenment Scotland. Ábrahám Kovács (Ed.), Reformed Churches Working Unity in Diversity: Global Historical, Theological and Ethical Perspectives, 46-60.

Friedenberg JD, Silverman GW. (2016). Cognitive Science: An introduction to the study of mind. SAGE Publications. Translated by Habibollah Ghassemzadeh, 1395, Arjmand Publication: Tehran, Iran. (InPersian)

Froese T, Ziemke T. (2009). Enactive artificial intelligence: investigating the systemic organization of life and mind. Artif. Intell, 173,466-500.

Ghassemzadeh H. (2007). An introduction to cognitive science. Bulletin of The Center for Research on Cognition, Behavior and Culture( CRCBC), 11-15. (In Persian)

Ghassemzadeh H. (2014). Cognition: From amodal representation to embodiment and synesthesia In Ghassemzadeh et al.(Eds.) Brain, Cognition and Behavior- A Collection of Seminar Papers- Vol.1, 73-113. (In Persian)

Greeno JG, Moore JL. (1993). Situativity and Symbols: Response to Vera and Simon. Cognitive Science, 17, 49-59.

Hilgard ER. (1980). The trilogy of mind: Cognition, affection, and conation. Journal History of the Behavioral Sciences, 16, 107-117.

Lemmen R. (1997). Towards a non-cartesian cognitive science in the light of the philosophy of Merleau-Ponty. The university of Sussex. $\mathrm{PhD}$ thesis.

Matlin M. (2009). Cognition. John Wiley \& Sons.

McNemey S. (2011). A brief guide to embodied cognition: Why you are not your brain? Scientificamerican.com

Miller GA, Gazzaniga MS. (1984). The Cognitive Sciences. In the Handbook of Cognitive Neuroscience. Edited by Michael $\mathrm{S}$. Gazzaniga. New York: PlenumPress.

Miller GA. (2003). The cognitive revolution: a historical perspective. Trends in Cognitive Sciences,7.

$$
\begin{aligned}
& \text { است كه به نظر مىرسد با توجه به دستاوردهاى علوم }
\end{aligned}
$$

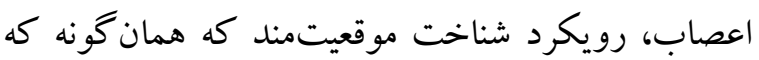

$$
\begin{aligned}
& \text { كَته شد، در آراء ويخو تسكى ريشه دارد، به دليل آنكه } \\
& \text { نقش محيطهاى مختلف فيزيكى، اجتماعى، فرهنكى، و } \\
& \text { زبانى را در شكل گيرى شناخت مؤثر مىداند، رويكردى } \\
& \text { جامع تر از ساير ديدكاهها داشته باشد. از اين رو، شايسته } \\
& \text { است بثوهش گران عرصه صاى مختلف شناخت بيزوهى به } \\
& \text { اين رويكرد بيشتر بيردازند و آن را به بوته آزمايش } \\
& \text { كذارند. }
\end{aligned}
$$

\section{References}

Andringa TC, Van Den Bosch KA, Wijermans N. (2015). Cognition from life: the two modes of cognition that underlie moral behavior. Front Psychol, 6: 362.

Brown JS, Collins A, Duguid P. (1989). Situated cognition and the culture of learning. Educational researcher, 18(1), 32-42.

Clark A. (2001). Being There: Putting Brain, Body, and World Together Again. Cambridge, MA: MITPress.

Clark A. (2008). Pressing the flesh: a tension in the study of the embodied, embedded mind? Philos. Phenomenol. Res. 76, 37-59.

Cobb P. (2001). Situated Cognition: Origins. In International Encyclopedia of the Social \& Behavioral Sciences.

Di Paolo EA, Rohde $M$, De Jaegher $H$. (2010). "Horizons for the enactive mind: values, social interaction, and play," in Enaction: Toward a New Paradigm for Cognitive Science, eds Stewart J., Gapenne O., Di Paolo E. A. Cambridge, MA: MIT Press, 34-87.

No.3: 141-144. Translated by Habibollah Ghassemzadeh. Baztabe Danesh, 23 \& 24, 9 14. 
Neisser U. (1967). Cognitive Psychology. Classic Edition published 2014 by Psychology Press.

Revlin R. (2012). Cognition: Theory and Practice. Worth Publishers.

Robbins P, Aydede M. (2009). A short primer on situated cognition. In the Cambridge Handbook of Situated Cognition. Cambridge University Press.

Rowlands M. (2010). The mind embedded. In The new science of the mind: from extended mind to embodied phenomenology. MIT press.

Schultz DP, Schultz SE. (2007). A History of Modern Psychology. Wadsworth Publishing; 9th edition.

Shafiei F, Ghassemzadeh H. (2018). Some reflections on representation and embodiment in cognitive psychology and cognitive science. Shenakht Journal of Psychology and Psychiatry: 5. No.1, 77-95. (In Persian)

Shapiro L. (2014). The Routledge Handbook Book of Embodied Cognition. Routledge.

Von Eckardt B. (1996). What is cognitive science? Princeton, MA: MIT Press.

Wilson RA, Foglia L. (2015). Embodied Cognition. StanfordEncyclopedia of Philosophy.

Wilson RA, Keil FC. (1999). The MIT Encyclopedia of the Cognitive Sciences. Massachusetts Institute of Technology. 